Tsaqofiya : Jurnal Pendidikan Bahasa dan Sastra Arab

Vol. 4 No. 1 Januari 2022, 16-27

P-ISSN : 2685-7022, E-ISSN : 2685-7103

DOI : $10.21154 /$ tsaqofiya.v4i1.57

\title{
Upaya Peningkatan Kemampuan Menyusun Bahan Ajar Online Bagi Guru Bahasa Arab Di Kabupaten Ponorogo
}

\author{
Ali Ba'ul Chusna', Ahmad Mujib' ${ }^{2}$, Kholidah Antun F. ${ }^{3}$ \\ IAIN Ponorogo \\ uul_chusna@iainponorogo.ac.id
}

\section{Abstract}

The need for teaching materials becomes something very important in learning activities. Especially during the current covid-19 pandemic where learning activities that are usually carried out face-to-face are directly replaced with distance learning by utilizing technological sophistication as a medium. In this case, teachers are required to be able to prepare teaching materials properly so that learning activities will continue to take place well, effectively, efficiently, and fun. This article aims to describe efforts to increase teacher competence in compiling online teaching materials for Arabic language teachers in the Ponorogo Regency area and the results achieved after participating in the preparation of online teaching materials. The service method used is participatory action research (PAR) which consists of four stages, namely mapping or problem mapping; action planning; implementation of actions; and evaluation. Efforts to improve the ability to compose online teaching materials were carried out in the form of training which was attended by 16 teachers from both Tsanawiyah and Aliyah madrasas in the Ponorogo Regency area. This activity was carried out in two stages with the presenters being the teaching team consisting of lecturers in the Arabic Language Education Department of IAIN Ponorogo. The material presented is the preparation of teaching materials based on power point and video. The results of the service show that participants are able to compile teaching materials using power point programs and videos to then be uploaded as online learning media.

Keywords: skills, teaching materials, online learning, Arabic

\section{Asbtrak}

Kebutuhan akan bahan ajar menjadi sesuatu yang sangat penting dalam kegiatan pembelajaran. Terlebih dalam masa pandemi covid-19 saat ini dimana kegiatan pembelajaran yang biasanya dilaksanakan secara tatap muka langsung berganti dengan pembelajaran jarak jauh dengan memamfaatkan kecanggilan teknologi sebagai medianya. Dalam hal ini, guru dituntut untuk mampu mempersiapkan bahan ajar dengan baik sehingga kegiatan pembelajaran akan tetap berlangsung dengan baik, efektif, efisien, dan menyenangkan. Artikel ini bertujuan untuk mendeskripsikan upaya peningkatan kompetensi guru dalam menyusun bahan ajar online bagi guru Bahasa Arab di wilayah Kabupaten Ponorogo serta hasil yang dicapai setelah mengikuti kegiatan penyusunan bahan ajar online tersebut. Metode pengabdian yang digunakan adalah participatory action research (PAR) yang 
terdiri dari empat tahap, yaitu mapping atau pemetaan masalah; perencanaan tindakan; pelaksanaan tindakan; dan evaluasi. Upaya peningkatan kemampuan menyusun bahan ajar online dilaksanakan dalam bentuk pelatihan yang diikuti oleh para guru baik dari madrasah Tsanawiyah maupun madrasah Aliyah di wilayah Kabupaten Ponorogo sebanyak 16 orang. Kegiatan ini dilaksanakan selama dua tahap dengan pemateri adalah tim teaching yang terdiri dari dosen jurusan Pendidikan Bahasa Arab IAIN Ponorogo. Materi yang disampaikan adalah penyusunan bahan ajar berbasis power point dan video. Hasil pengabdian menunjukkan bahwa peserta mampu menyusun bahan ajar dengan menggunakan program power point maupun video untuk kemudian diupload sebagai media pembelajaran online

Kata Kunci: kemampuan, bahan ajar, pembelajaran online, Bahasa Arab

\section{PENDAHULUAN}

Perkembangan dunia industri dan pembangunan tidak lagi menjadi ciri utama dari kemajuan suatu bangsa. Kemajuan ini dapat dilihat juga dari penggunaan bahasa yang semakin meningkat dalam berbagai ranah kehidupan masyarakat. Bahasa yang dimaksud disini tidak sebatas pada bahasa ibu maupun Bahasa nasional bangsa sebagai bahasa utama, akan tetapi juga pada bahasa asing yang penguasaan dan penggunaannya semakin banyak dibutuhkan seiring perkembangan ilmu pengetahuan dan teknologi seperti saat ini. ${ }^{1}$

Kebutuhan akan penguasaan Bahasa asing yang semakin meningkat menjadikan materi pembelajaran Bahasa asing banyak diminati di lembaga-lembaga pendidikan, di antaranya adalah Bahasa Arab. Bahasa nasional negara-negara Timur Tengah yang mulanya dikenal sebagai bahasa agama telah berkembang menjadi bahasa komunikasi internasional sejajar dengan basa asing lainnya sebagaimana diakui oleh lembaga perdamaian dunia (PBB). ${ }^{2}$

Sebagaimana keterampilan bahasa yang lain. keterampilan dalam Bahasa Arab mencakup empat hal, yaitu istima', kalam, qiro'ah, dan kitabah. Dari empat keterampilan tersebut, yang termasuk dalam kategori keterampilan bersifat reseptif adalah membaca (qiro'ah) dan menyimak (istima'). Dalam membaca dan menyimak, bahan atau sumber telah tersedia dan manusia dapat langsung menerima informasi yang dibutuhkan dalam kegiatan tersebut. Adapun keterampilan yang termasuk

1 Minto Rahayu, Bahasa Indonesia di Perguruan Tinggi: Mata Kuliah Pengembangan Kepribadian (Jakarta: Grasindo, 2007), 5

2 Jamaluddin Shiddiq, "Inovasi Pemanfaatan Word-Wall Sebagai Media Game-Based Learning Untuk Bahasa Arab," JALIE; Journal of Applied Linguistics and Islamic Education 5, no. 1 (2021): 151-69. 
dalam kategori produktif adalah kitabah (menulis) dan kalam (berbicara). Dua keterampilan tersebut menuntut kita untuk dapat menuangkan ide-ide, baik tertulis maupun lisan. ${ }^{3}$

Berbeda dengan bahasa ibu (bahasa Indonesia) yang cenderung lebih mudah dipelajari, bahasa Arab sebagai asing memiliki tingkat kesulitan tersendiri dalam mempelajarinya. ${ }^{4}$ Berbagai macam kesulitan dihadapi, baik oleh guru ataupun siswa. Kesulitan-kesulitan tersebut membuat Bahasa Arab menjadi materi yang sulit dikuasai oleh para siswa. ${ }^{5}$

Berbagai macam upaya dapat dilakukan untuk meminimalisir problematika pembelajaran Bahasa Arab yang ada di sekolah ataupun madrasah. Terlebih pada masa pandemi covid-19 yang tengah melanda dunia saat ini. Semua aspek kehidupan mengalami dampak serius sebagai akibat dari adanya pandemi ini. Begitu juga dalam dunia pendidikan. Kegiatan pembelajaran yang awalnya dilakukan secara tatap muka berubah menjadi tatap maya atau yang dikenal dengan pembelajaran daring (dalam jaringan) dengan memanfaatkan jaringan internet. Dalam hal ini, seorang guru dituntut untuk mampu mengemas kegiatan pembelajaran dengan lebih baik. Materi tersampaikan dengan baik dan dapat diterima serta dipahami oleh siswa.

Untuk mewujudkan hal tersebut, guru dapat melakukan inovasi pembelajaran, baik dari segi strategi pembelajaran, media pembelajaran, maupun materi ajar yang disampaikan. Berbagai macam inovasi tersebut dimaksudkan supaya pembelajaran dapat berjalan lebih menarik, efektif, dan efisien sehingga mampu membantu siswa dalam memahami materi.

Materi ajar memiliki peranan penting dalam pembelajaraan Bahasa Arab disamping strategi dan media yang digunakan oleh guru. Ketersediaan materi menjadi salah satu penentu keberhasilan kegiatan pembelajaran. Materi yang disusun sesuai dengan standar kompetensi yang ingin dicapai akan menjadikan pembelajaran berjalan dengan baik sebagaimana yang diharapkan.

\section{3), 3-4}

${ }^{3}$ Henry Guntur Tarigan. Berbicara Sebagai Suatu Keterampilan Berbahasa (Bandung: Angkasa,

4 Y. Hidayat. 2008. Studi Prinsip Dasar Metode Pengajaran Bahasa Arab (online). http://arabicforall.or.id/metode/studi-prinsip-dasar-metode-pengajaran-bahasa-arab. Diakses 26 September 2020

5 Muhammad Nur Kholis, "Proses Interferensi Fonologi Pada Percakapan Bahasa Arab Santri," Tsaqofiya: Jurnal Pendidikan Bahasa Dan Sastra Arab 1, no. 2 (2019): 1-18. 
Ketersediaan akan bahan ajar yang sesuai dengan standar kompetensi yang telah ditetapkan serta selaras dengan perubahan ilmu pengetahuan dan teknologi belum banyak ditemui. Mayoritas buku ajar bahasa yang digunakan di tiap madrasah masih bersifat monoton, dengan tampilan yang kurang menarik, dan tidak disertai dengan ilustrasi-ilustrasi yang dapat membantu pemahaman siswa. Guru hanya menggunakan bahan ajar yang diperoleh dari pemerintah tanpa ada usaha berinovasi supaya bahan ajar memiliki tampilan yang menarik.

Adapun tujuan dari pengabdian ini untuk mendeskripsikan upaya yang dilakukan oleh tim pengabdian IAIN Ponorogo dalam meningkatkan kompetensi penyusunan bahan ajar online bagi guru Bahasa Arab di wilayah Kabupaten Ponorogo dan hasil yang berhasil dicapai oleh para peserta selama mengikuti kegiatan.

Tema kegiatan pelatihan penyusunan bahan ajar online ini tentu bukanlah yang pertama dilakukan. Beberapa tim pengabdian dari beberapa daerah telah melakukan kegiatan pengabdian dengan tema ini. Diantaranya adalah: 1) Pelatihan Penyusunan Bahan Ajar Bahasa Indonesia bagi Guru SMP/MTs di Surakarta yang dilakukan oleh Miftakhul Huda dan Rahmah Purwahida. Kegiatan ini dilaksanakan selama satu hari dengan diikuti oleh 13 orang guru SMP/MTs di kota Samarinda dengan hasil para peserta mampu menyusun bahan ajar Bahasa Indonesia tingkat SMP/MTs. ${ }^{6}$ 2) Pelatihan Pembuatan bahan ajar Berbasis Multimedia Bagi Guru di Samarinda yang dilakukan oleh Tien Rahayu Yulili, Yusni Nyura, dan Wahyuni Eka Sari. Hasil dari kegiatan ini adalah 18 orang peserta mulai terbiasa mengoperasikan perangkat lunak (komputer atau laptop) dan mampu membuat bahan ajar dengan memanfaatkan multimedia. ${ }^{7}$ 3) Pendampingan Pengembangan Bahan Ajar Sejarah Makanan Tradisional Kudus yang dilakukan oleh Imaniar Purbasari dan Nur Fajrie. Kegiatan ini diikuti oleh para guru Sekolah Dasar di Kabupaten Kudus dan menghasilkan produk bahan ajar yang kemudian dapat dijadikan sebagai referensi dalam materi pengenalan makanan tradisional Kudus. ${ }^{8}$

6 Miftakhul Huda dan Rahmah Purwahida, Pelatihan Penyusunan Bahan Ajar Bahasa Indonesia bagi Guru SMP/MTs di Surakarta, Warta LPM: Media Informasi dan Komunikasi Hasil Pengabdian kepada Masyarakat. Vol. 13 No. 1 Maret 2010, hal

7 Tien Rahayu Yulili, Yusni Nyura, dan Wahyuni Eka Sari, Pelatihan Pembuatan bahan ajar Berbasis Multimedia Bagi Guru di Samarinda, Prosiding Seminar Hasil Pengabdian (SNP2M), 2018, hal 191-196.

8 Imaniar Purbasari dan Nur Fajrie, Pendampingan Pengembangan Bahan Ajar Sejarah Makanan Tradisional Kudus, Muria Jurnal Layanana Masyarakat. Vol. 1 No. 1 Maret 2019 
Kegiatan pengabdian yang dilakukan oleh tim pengabdian IAIN Ponorogo berbeda dengan beberapa pengabdian tersebut di atas. Kegiatan pengabdian ini difokuskan pada penyusunan bahan ajar Bahasa Arab.

\section{METODE}

Metode pengabdian yang digunakan adalah participatory action research (PAR) dengan menggunakan prinsip emancipatory dalam melakukan pengorganisasan masyarakat melalui pendidikan orang dewasa (andragogi). Hal ini didasarkan pada permasalahan yang telah ditemukan oleh tim pengabdian pada studi pendahuluan sebagaiman dipaparkan dalam fokus program di atas. Aktor utama (main actor) dalam kegiatan pengabdian ini adalah guru Bahasa Arab Kabupaten Ponorogo, sedangan tim dari IAIN Ponorogo berperan sebagai pendamping yang semaksimal mungkin berusaha untuk menumbuhkan dan meningkatkan kesadaran, partisipasi, dan potensi yang telah dimiliki oleh guru Bahasa Arab di wilayah kabupaten Ponorogo.

Dalam kegiatan pengabdian ini, tim pengabdian akan melakukan pendampingan terhadap guru-guru Bahasa Arab di wilayah kabupaten Ponorogo dalam memetakan, merumuskan masalah, membuat rencana tindakan, melaksanakan program kegiatan, memantau dan mengevaluasi setiap implementasi program. Pada setiap tahapan proses tersebut, tim pengabdian berusaha membangun suasana dan menciptakan iklim kondusif dengan memberikan berbagai macam saran sehingga kompetensi yang diharapkan semakin meningkat

\section{PEMBAHASAN}

1. Upaya Peningkatan Kemampuan Menyusun Bahan Ajar Online Bagi Guru Bahasa Arab Di Wilayah Kabupaten Ponorogo

Kegiatan pengabdian ini terdiri dari empat tahapan, yaitu pemetaan, penyusunan rencana tindakan, pelaksanaan kegiatan pengabdian, dan evaluasi.

a) Kegiatan pemetaan (mapping) potensi, permasalahan, dan tantangan yang dihadapi oleh Guru Bahasa Arab di Kabupaten Ponorogo

Kegiatan ini merupakan tindak lanjut dari riset pendahuluan (preliminary research) yang telah dilakukan oleh tim pengabdian. Dalam hal ini guru-guru 
Bahasa Arab didampingi untuk melakukan observasi terhadap kebutuhan bahan ajar. Kegiatan ini dimaksudkan untuk mendapatkan gambaran utuh akan kebutuhan, potensi dan permasalahan yang dihadapi para guru terkait penyusunan bahan ajar Bahasa Arab. Satu hal yang sangat penting mengingat paradigma pembangunan yang bertumpu pada komunitas (community based development) memerlukan kesadaran akan adanya masalah bersama yang harus dipecahkan secara bersama pula. Luaran (output) yang dari kegiatan ini adalah dihasilkannya peta permasalahan, kebutuhan dan potensi guru dalam penyusunan bahan ajar.

Kegiatan pemetaan ini dilaksanakan dengan melakukan wawancara terhadap beberapa guru Bahasa Arab di wilayah kabupaten Ponorogo. Dari hasil wawancara secara langsung maupun melalui media social whatsapp terhadap beberapa guru Bahasa Arab baik tingkat Tsanawiyah maupun Aliyah di madrasah wilayah kabupaten Ponorogo, diketahui beberapa problematika pembelajaran Bahasa Arab yang dihadapi oleh para guru dewasa ini. Dari beberapa permasalahan yang diutarakan, terdapat tiga masalah utama yang banyak dihadapi saat ini, yaitu bahan ajar, media pembelajaran, dan metode pembelajaran.

Pertama adalah keterbatasan akan bahan ajar. Guru menggunakan bahan ajar yang diperoleh dari buku ajar terbitan Kemenag tanpa melakukan pengembangan maupun inovasi. Bagi mereka, materi Bahasa Arab yang sangat banyak memberikan beban tersendiri kepada mereka untuk dapat menyelesaikan materi secara keseluruhan dalam waktu tertentu sebagaimana ditetapkan dalam kurikulum. Dan permasalahan ini semakin meningkat ketika pembelajaran dilaksanakan secara daring. Guru yang terbiasa menyampaikan materi di depan kelas dengan berbekal buku materi, spidol, dan papan tulis dituntut untuk dapat menemukan cara supaya materi dapat tersampaikan dengan baik dan dipahami oleh siswa.

Kedua adalah media pembelajaran. Tidak semua guru memiliki kemampuan dalam menggunakan media pembelajaran. Terlebih media pembelajaran berbasis teknologi. Kegiatan pembelajaran online sebagai dampak dari kemajuan ilmu pengetahuan dan teknologi serta pandemi covid-19 yang sedang dihadapi oleh dunia, memaksa pelaku dunia pendidikan untuk dapat 
menggunakan kemajuan teknologi sebagai sarana pembelajaran. Untuk itu, seorang pendidik dituntut untuk mampu menggunakan media pembelajaran berbasis teknologi dalam menunjang kegiatan pembelajaran yang dilaksanakan.

Ketiga adalah metode pembelajaran. Sebagai Bahasa asing, Bahasa Arab memiliki materi yang begitu kompleks. Hal ini tidak jarang membuat siswa bingung dalam memahami materi. Bahkan, tidak jarang dari mereka menyatakan bahwa mempelajari Bahasa Arab sangat sulit dan membosankan. Dalam hal ini, guru harus memiliki strategi khusus dalam menyampaikan materi sehingga pembelajaran menjadi lebih menarik dan dapat diterima serta difahami oleh siswa. Guru harus mampu menguasai berbagai macam metode pembelajaran Bahasa asing, khususnya dalam pembelajaran Bahasa Arab.

Selain pemetaan masalah, hasil wawancara dan observasi awal yang dilakukan oleh tim pengabdian bertujuan untuk mengetahui potensi yang telah dimiliki oleh para guru yang dapat dikembangkan sebagai upaya untuk memecahkan permasalahan yang tengah dihadapi. Potensi yang dimiliki oleh para guru disini adalah keilmuan Bahasa Arab yang yang mereka miliki sebagai seorang pengajar Bahasa Arab. Kemampuan mereka dalam menguasai ilmu-ilmu terkait pembelajaran Bahasa Arab dapat menjadi modal utama dalam menyelesaikan permasalahan, baik dalam hal kaitannya dengan bahan ajar, media pembelajaran, maupun metode pembelajaran.

\section{b) Penyusunan Rencana Tindakan}

Setelah diperoleh peta dasar kebutuhan, potensi dan permasalahan yang dihadapi oleh para guru dalam penyusunan bahan ajar, maka kegiatan berikutnya adalah penyusunan rencana tindakan berupa pelatihan penyusunan bahan ajar. Rencana Tindakan tersebut memuat identifikasi permasalahan yang dihadapi oleh guru, strategi pemecahan masalah, pengembangan berbagai pilihan tindak/kegiatan, rencana implementasi, dan kegiatan monitoring/evaluasi.

Pada tahap ini, tim melakukan focuss group discussion (FGD). Dalam kegiatan ini, dibahas rencana-rencana tindakan pendampingan berdasarkan atas peta permasalahan yang telah diperoleh dari hasil wawancara dengan beberapa perwakilan guru, baik secara langsung maupun melalui media komunikasi whatssapp. 
Dari permasalahan yang diperoleh saat observasi awal, tim pengabdian memutuskan untuk mengambil salah satu permasalahan yang dianggap sangat penting dan dihadapi hampir seluruh guru Bahasa Arab saat ini, baik kalangan muda maupun senior, yaitu permasalahan penyusunan bahan ajar.

Kegiatan FGD yang dilakukan oleh tim pengabdian menghasilkan kesepakatan untuk melaksanakan kegiatan pelatihan penyusunan bahan ajar sebagai solusi permasalahan yang dihadapi oleh para guru dalam penyusunan bahan ajar. Selain itu, disepakati pula narasumber yang akan mengisi dalam kegiatan ini dan jadwal pelaksanaan kegiatan yang akan dilaksanakan sebanyak dua tahap. Kegiatan tahap pertama adalah penyampaian materi dan latihan. Sedangkan kegiatan tahap dua adalah tindak lanjut yang dimaksudkan untuk evaluasi hasil kerja dari kegiatan tahap pertama.

\section{c) Melaksanakan Kegiatan Pelatihan}

Sesuai dengan hasil FGD yang telah dilaksanakan, maka kegiatan ini dilaksanakan dalam dua tahap. Tahap pertama adalah pelatihan penyusunan bahan ajar, dan kegiatan tahap dua adalah materi lanjutan berupa penyusunan bahan ajar online sekaligus evaluasi dari kegiatan pelatihan.

Sebelum melaksanakan kegiatan, tim melakukan FGD dengan tujuan untuk koordinasi yang dihadiri oleh lima orang. Kegiatan ini dilaksanakan pada tanggal 30 Mei 2021. Dalam kegiatan ini disepakati bahwa kegiatan akan dilaksanakan di MTs Ma'arif Ponorogo dan MA Ma'arif Ponorogo. Kedua madrasah tersebut berada di bawah Yayasan Ma'arif Ponorogo dan bertempat di satu lokasi. Selain itu, dalam kegiatan FGD ini juga dibahas hal-hal terkait persiapan pelaksanaan kegiatan. Diantaranya adalah jadwal kegiatan, penanggung jawab setiap kegiatan, administrasi dan persuratan, koordinasi dengan pihak madrasah/sekolah, kelengkapan workshop, dan konsumsi kegiatan.

1) Kegiatan tahap 1

Kegiatan ini dilaksanakan pada tanggal 5 Juni 2021 bertempat di MTs Ma'arif Putri Ponorogo. Kegiatan ini dihadiri oleh 16 orang guru Bahasa Arab MTs/MA di wilayah Kabupaten Ponorogo. Kegiatan ini dimulai pada pkl. 08.00 WIB sampai pkl 13.30 WIB. 
Kegiatan dimulai pukul 07.30 WIB yang diawali dengan pembukaan. Acara dibuka oleh Kepala Madrasah Tsanawiyah, Bapak Imam Machmudi, M.Ag dan perwakilan tim pengabdian dari IAIN Ponorogo.

Untuk kegiatan pelatihan dibagi ke dalam dua sesi yang diisi oleh dua orang narasumber, yaitu Rizka Ellyana Maslihah, M. Pd dan Ali Ba'ul Chusna, M.S.I. Pada sesi pertama, disampaikan materi-materi terkait teknis penyusunan bahan ajar yang disampaikan oleh Rizka Ellyana Maslihah, M. Pd dan pada sesi kedua adalah materi tentang menyusun bahan ajar inovatif yang disampaikan oleh Ali Ba'ul Chusna, M.S.I.

Selain menerima materi pelatihan, peserta juga diminta untuk berlatih menyusun bahan ajar secara langsung dengan didampingi oleh narasumber dan tim pengabdian secara langsung. Bahan ajar yang telah dihasilkan oleh peserta kemudian dipaparkan dan didiskusikan secara bersama-sama.

Pada akhir pelatihan tahap 1 ini, peserta diberi kesempatan untuk bertanya terkait materi yang belum dipahami maupun sharing pengalaman terkait penyusunan bahan ajar yang pernah mereka lakukakn sebelumnya.

2) Kegiatan tahap 2

Kegiatan ini bertempat di aula pertemuan MA Ma'arif Putri Ponorogo dengan dihadiri oleh 16 orang peserta baik dari tingkat MTs maupun MA di wilayah Ponorogo. Pada tahap 2 ini, kegiatan pelatihan dilaksanakan dengan mendatangkan dua orang narasumber. Yaitu Rizka Ellyana M., M.Pd dan Zamzam Musthofa, M. Pd. Keduanya adalah dosen pada Jurusan Pendidikan Bahasa Arab IAIN Ponorogo.

Kegiatan dibuka oleh kepala MA Ma'arif Putri Ponorogo, Bapak Musthofa Kamalie, M.Ag bersama dengan tim pengabdian IAIN Ponorogo pada pukul 07.30 WIB. Kemudian kegiatan dilanjutkan dengan penyampaian materi oleh narasumber.

Materi pertama disampaikan oleh Zamzam Musthofa, M. Pd dengan materi pembuatan bahan ajar Bahasa Arab online berbasis power point. Sedangkan materi kedua tentang pembuatan bahan ajar berbasis video disampaikan oleh Rizka Ellyana M., M.Pd.

\section{d) Evaluasi}


Evaluasi merupakan tahap akhir dari kegiatan pelatihan penyusunan bahan ajar online bagi guru Bahasa Arab di wilayah Kabupaten Ponorogo yang telah dilakukan. Kegiatan evaluasi dilakukan di akhir acara pelatihan tahap 2. Kegiatan ini berisi evaluasi terhadap hasil kegiatan pelatihan yang telah dilakukan.

Dalam tahapan ini, peserta memaparkan hasil pelatihan yang telah diikuti berupa bahan ajar online yang telah mereka susun. Kemudian narasumber memberikan feedback terhadap bahan ajar online yang telah disusun oleh peserta.

Selain itu, tim pengabdian juga melakukan evaluasi kegiatan yang dilakukan guna mengetahui kekurangan dan respon peserta terhadap kegiatan yang telah dilaksanakan. Dari 16 orang peserta yang hadir mengikuti kegiatan, terdapat 12 orang peserta (75\%) yang menyatakan sangat puas dan dapat memahami materi pelatihan dengan baik. Sedangkan 4 orang lainnya (25\%) merasa puas dan merasa cukup kesulitan mengikuti materi, khususnya pada materi pembuatan bahan ajar berbasis video. Keempat peserta tersebut merupakan para guru senior dan memiliki kelemahan dalam pengoperasian media berbasis teknologi.

\section{Hasil Kegiatan Pengabdian}

Kegiatan pelatihan penyusunan bahan ajar online bagi guru Bahasa Arab di wilayah kabupaten Ponorogo memberikan hasil yang sangat baik dan mampu meningkatkan kompetensi mereka dalam menyusun bahan ajar online. Terdapat dua materi utama dalam kegiatan ini, yaitu penyusunan bahan ajar berbasis power point dan penyusunan bahan ajar berbasis video. Hal ini nampak dari antusia para peserta ketika narasumber menjelaskan materi. Berbagai pertanyaan terkait kendala penggunaan power point yang selama ini mereka hadapi tak luput dari pembahasan dalam kegiatan ini. Dan dari hasil kerja yang dipaparkan oleh para peserta, nampak bahwa mereka telah menguasai materi lebih baik dari sebelumnya. Dari model power point yang mulanya sangat sederhana, telah meningkat menjadi lebih menarik karena permainan warna dan animasi yang dipelajari sebelumnya.

Dalam materi pembuatan bahan ajar online berbasis video, sebagian peserta menyatakan bahwa ini merupakan materi baru bagi mereka. Sebagian 
peserta menyatakan telah mengenal materi ini, akan tetapi belum mendalam. Dari hasil pelatihan, diketahui bahwa peserta juga antusias dalam materi ini. Hasil kerja yang dikumpulkan menunjukkan bahwa sebagian peserta dapat memahami materi dengan baik dan mampu mengaplikasikan program dalam menyusun bahan ajar. Mereka mampu membuat bahan ajar berbasis video dengan menggunakan aplikasi Bandicam. Materi ajar yang disusun pun menjadi semakin menarik. Akan tetapi, terdapat beberapa orang peserta yang belum mampu memahami materi dengan baik. Empat orang tersebut adalah para peserta senior yang kurang mampu menguasai IT sehingga kesulitan dalam pengoperasian media pembelajaran.

Mayoritas guru masih menggunakan whatsapp group sebagai media pembelajaran online, sehingga bahan ajar berbasis power point dan video yang telah dihasilkan oleh para guru tersebut dapat langsung digunakan dalam kegiatan pembelajaran. Para guru dapat mengupload materi tersebut secara langsung dalam whatsapp group kelas maupun chanel youtube guru untuk kemudian dibagikan link-nya kepada para siswa.

\section{SIMPULAN}

Kemajuan teknologi dan yang begitu pesat hendaknya juga disertai dengan peningkatan kompetensi guru sehingga mampu mengikuti perkembangan ilmu pengetahuan dan teknologi yang ada. Seorang guru dituntut untuk mampu mengemas bahan ajar menjadi lebih menarik sehingga kegiatan pembelajaran dapat berlangsung dengan efektif dan efisien. Pelatihan membuat bahan ajar online ini diharapkan mampu memberikan bekal pada guru dalam meningkatkan kompetensi tersebut.

\section{DAFTAR PUSTAKA}

Miftakhul Huda dan Rahmah Purwahida, Pelatihan Penyusunan Bahan Ajar Bahasa Indonesia bagi Guru SMP/MTs di Surakarta, Warta LPM: Media Informasi dan Komunikasi Hasil Pengabdian kepada Masyarakat. Vol. 13 No. 1 Maret 2010 Purbasari, Imaniar dan Nur Fajrie, Pendampingan Pengembangan Bahan Ajar Sejarah Makanan Tradisional Kudus, Muria Jurnal Layanana Masyarakat. Vol. 1 No. 1 Maret 2019

Rahayu, Minto. Bahasa Indonesia di Perguruan Tinggi: Mata Kuliah Pengembangan Kepribadian. Jakarta: Grasindo, 2007 
Tarigan. Henry Guntur. Berbicara Sebagai Suatu Keterampilan Berbahasa. Bandung: Angkasa, 1983

Y. Hidayat. 2008. Studi Prinsip Dasar Metode Pengajaran Bahasa Arab (online).http://arabicforall.or.id/metode/studi-prinsip-dasar-metodepengajaran-bahasa-arab. Diakses 26 September 2020

Yulili, Tien Rahayu; Yusni Nyura; dan Wahyuni Eka Sari, Pelatihan Pembuatan bahan ajar Berbasis Multimedia Bagi Guru di Samarinda, Prosiding Seminar Hasil Pengabdian (SNP2M), 2018

Kholis, Muhammad Nur. "Proses Interferensi Fonologi Pada Percakapan Bahasa Arab Santri." Tsaqofiya: Jurnal Pendidikan Bahasa Dan Sastra Arab 1, no. 2 (2019): 118.

Shiddiq, Jamaluddin. "Inovasi Pemanfaatan Word-Wall Sebagai Media Game-Based Learning Untuk Bahasa Arab." JALIE; Journal of Applied Linguistics and Islamic Education 5, no. 1 (2021): 151-69. 